\title{
Correction: Knowledge management for policy impact: the case of the European Commission's Joint Research Centre
}

\author{
Lene Topp ${ }^{1}$, David Mair ${ }^{1}$, Laura Smillie ${ }^{1} \&$ Paul Cairney ${ }^{2}$
}

Correction to: Palgrave Communications https://doi.org/10.1057/s41599-018-0143-3, Published online 10 July 2018.

The affiliation for authors Lene Topp, David Mair and Laura Smillie was incorrectly stated as "Joint Research Centre, European Commission, Retieseweg 111, 2440, Geel, Belgium". This has been corrected to "Joint Research Centre, European Commission, Brussels, Belgium".

In Table 2, the row labelled "Advising policymakers", in the column labelled "The cautionary tale" the cell reads "Researchers become marginalised and rarely trusted in day to day politics. Policymakers receive evidence but remain sure about its relevance and risk of inaction". This has been corrected to "The cautionary tale" the cell reads "Researchers become marginalised and rarely trusted in day to day politics. Policymakers receive evidence but remain unsure about its relevance and risk of inaction".

This has been corrected in both the HTML and PDF versions of this paper.

Published online: 18 September 2018

\footnotetext{
(c) Open Access This article is licensed under a Creative Commons Attribution 4.0 International License, which permits use, sharing, adaptation, distribution and reproduction in any medium or format, as long as you give appropriate credit to the original author(s) and the source, provide a link to the Creative Commons license, and indicate if changes were made. The images or other third party material in this article are included in the article's Creative Commons license, unless indicated otherwise in a credit line to the material. If material is not included in the article's Creative Commons license and your intended use is not permitted by statutory regulation or exceeds the permitted use, you will need to obtain permission directly from the copyright holder. To view a copy of this license, visit http://creativecommons.org/licenses/by/4.0/.
}

(C) The Author(s) 2018

\footnotetext{
${ }^{1}$ Joint Research Centre, European Commission, Brussels, Belgium. ${ }^{2}$ Division of History and Politics, University of Stirling, Stirling, Scotland. Correspondence and requests for materials should be addressed to P.C. (email: p.a.cairney@stir.ac.uk)
} 